\title{
Molecular Workbench Software as Computer Assisted Instruction to Aid the Learning of Chemistry
}

\author{
Elaheh Khoshouie ${ }^{1}$ \\ Ahmad Fauzi Mohd Ayub ${ }^{2,3}$ \\ Farhad Mesrinejad 4 \\ ${ }^{1}$ Department of Education, Isfahan, Iran \\ ${ }^{2}$ Faculty of Educational Studies, Universiti Putra Malaysia \\ 3Institute For Mathematical Research, Universiti Putra Malaysia \\ ${ }^{4}$ Majlesi Branch, Islamic Azad University, Isfahan, Iran \\ khoshuoie@yahoo.com, ahmad_fauzim@hotmail.com
}

\section{Doi:10.5901/jesr.2014.v4n3p373}

\begin{abstract}
This study carried out with 70 seventy secondary school students evaluated the usefulness of computer assisted instruction as an aid in the learning of chemistry in Iran. A treatment-control group design was used to test the impact of the Molecular Workbench software on students' test performance following the use of the software package. Independent sample t-tests showed that students who were taught using the Molecular Workbench software performed better in post-tests on five chemistry topics as compared with those who received conventional instruction. Students using the software also found this software useful in the learning of chemistry.
\end{abstract}

Keywords: molecular workbench, chemistry, computer assisted instruction

\section{Introduction}

Science teachers need to create a meaningful learning environment to enhance students' interest in their lessons as well as facilitate understanding of the subject. Recent developments in Information and Communications Technologies (ICT) provide new opportunities to improve teaching and learning in the classroom (Abdoolatiff \& Narod, 2009). ICT can create a powerful learning environment by providing avenues for students and educators to access an abundance of information using multiple information resources (Smeets, 2005). Besides that, ICT encourages individual-learning, teacher-tostudent interactions, student-to student interactions, and also conceptual understanding. According to Barak (2007), the use of ICT and visualization tools facilitates the comprehension of chemistry. One approach towards integrating ICT in teaching and learning is through the use of the computer, especially in the application of educational software in Computer Assisted Instruction (CAl). Physics, Chemistry and Biology are the science subjects most often taught in school. The common feature of these courses is their relating to both real objects and the experimental approach (Dasdemir, Doymus, Simsek, \& Karaçöp, 2008). In the process of learning, it is important to know what previous knowledge students have brought to the classroom so that past experience can help in generating new knowledge (Tsai, 2000). In science education, chemistry is one of the important subjects that incorporate many complex concepts. Chemistry knowledge can be described at three levels: the macroscopic, the sub microscopic and the symbolic (Johnstone, 1982). The interactions between molecules and atoms which take place at a sub microscopic level need to be properly illustrated by instructors before students can appreciate the concepts fully (Ozmen, Ayas, \& Costu, 2002). Notions such as the particulate nature of matter, physical and chemical change, chemical equilibrium, solutions, acids and bases, chemical bonding, and the conservation of mass are topics that students often have difficulty in visualizing at the sub microscopic level (Tyson, Treagust \& Bucat, 1999). CAl allows students to understand and visualize processes such as chemical and physical processes easily, and this is very important in the learning of chemistry (Demirad, Kartal, \& Tuysuz, 2008). It has been reported that CAl can develop students' ability to understand and evaluate scientific processes (Cepni, Tas \& Kose, 2006). One popular strategy in teaching science involves the use of computer simulations to advance learning about unobservable phenomena in science since computer simulations enable students to visualize 
abstract and unobservable concepts (Gobert, Snyder, \& Houghton, 2002). Meaningful learning involves realigning, rearranging or replacing students' prior conceptions to accommodate new ideas; this process is known as conceptual change (Smith, Blakeslee, \& Anderson, 1993; Yuruk, 2007).

In traditional teaching methodologies, teacher-centred methods are used in teaching science subjects that may sometimes have a negative effect on the learners' beliefs about science (Kiboss, Ndirangu \& Wekesa, 2004). In this type of teaching, students see science learning as simply gathering facts, which may be boring and tedious. However, this perception may change through the use of the computer in ICT. Previous research has shown that using CAI could enhance the students' performance and understanding in every field.

In an experimental study, Barnea and Dori (1999) examined the performance of high-school students in computerized molecular modelling (CMM). Results of this study showed that the teaching and learning of topics in chemistry that are related to three dimensional structures could be improved in a computerized learning environment. Accordingly, the test scores of the students taught using CMM were significantly higher than those of the control group. Chang (2001) also supported the idea that computer assisted learning had positive effects on students' achievements. Students who were exposed to Problem Based Computer Assisted Instruction (PBCAl) achieved significantly higher test scores than students in the Direct Interactive Teaching Method (DITM) group. Ozmen and Kolomuc (2004) investigated the effects of the CAI on $10^{\text {th }}$ grade students' achievement in the solution concept and found that the experimental group that took CAl had a better understanding of the concept than the control group that received traditional instruction.

Morgil, Yavuz, Oskay and Arda (2005) compared traditional and computer-assisted learning in teaching the concept of acids and bases. They found a significant difference in the chemistry achievement test favouring the group learning chemistry using the Internet (experimental group) compared with that of the control group. Akcay, Durmaz, Tuysuz \& Feyzioglu (2006) conducted a study to compare the effectiveness of computer-based learning and the traditional method with regard to students' achievement in analytical chemistry. The post-test results showed that students exposed to computer based learning performed significantly better than students who were taught using the traditional method.

Frailich, Kesner and Hofstein (2007) investigated the influence of integrating a website into chemistry teaching on students' understanding of the concept of chemical bonding. They found that integrating a web-based learning environment enhanced the comprehension of chemistry concepts and increased students' awareness of the relevance of chemistry to daily life. Similarly, Dasdemir, Doymus, Simsek and Karaçöp, (2008) investigated the effects of computer animations on the teaching of acids and bases to primary school students. Students who were taught by computer supported animation showed better test performance than those in the traditional teaching group. Ozmen (2008) conducted another study on the effects of computer-assisted instruction on students' conceptual understanding of chemical bonding involving 11 grade students. The post-test scores from the Chemical Bonding Achievement Test showed a statistically significant difference in favour of the experimental group. Research findings also indicated that students using computers were more successful in the learning of alternative concepts. Abdoolatiff and Narod (2009) investigated the effectiveness of using computer simulations on students' understanding of "Atomic Structure and Bonding" over the traditionally designed instruction. The findings revealed an improved performance of students in the treatment group as compared with those in the control group. These results also indicated that computer simulations had not only enhanced students' understanding of "Atomic Structure and Bonding," but also increased their motivation during the lessons.

Hence it can be seen that integrating ICT into the curriculum, and utilizing the computer to teach and learn science using a variety of computer coursewares and online materials ensure that students get the best benefits from current information technology especially in understanding and to develop students' motivation in learning science. Rapid advancement in computer technology has helped researchers develop more inovative products to enable teaching and learning to be more effective in the classroom.

\section{Purpose}

This study seeks to investigate the effects of using the Molecular Workbench software on students' learning of chemistry. The topics investigated in this study are the gas laws, chemical bonding, electronegativity, molecular geometry and dissolution. This study analyzes the overall post-test scores as well as the score for each individual topic. Apart from that, the study looks into the students' perceptions of the usefulness of the Molecular Workbench software in learning chemistry. 


\section{Methodology}

This research was based on a quasi-experimental study coupled with non-equivalent control group post-tests. The research sample consisted of two homogeneous first grade students in a girls' school in the Borkhar area of the Isfahan province of Iran. Thirty-five students in each experimental group completed the tasks assigned. The traditional teaching methods were used to teach the subjects in the control group while the chemistry software, Molecular Workbench, was used in the treatment group.

\subsection{Instrumentation}

The chemistry performance post-test consisted of 20 subjective questions in five Chemistry topics, viz. the gas laws, chemical bonding, molecular electronegativity, molecular geometry and salt dissolution. All the questions were prepared by the chemistry teachers in the school and each topic has the same weight. The usefulness of learning chemistry using Molecular Workbench software as perceived by the students in the treatment group was also evaluated.

\subsection{Instructional Software}

The Molecular Workbench is a free open source software package for creating and delivering interactive scientific simulations and learning modules based on simulations for teaching and learning chemistry. Besides it being an open source software, Molecular Workbench was selected for this study because it contains chemistry topics matching the syllabus of Grade One secondary schools in Iran. Figure 1 illustrates the front page of the software
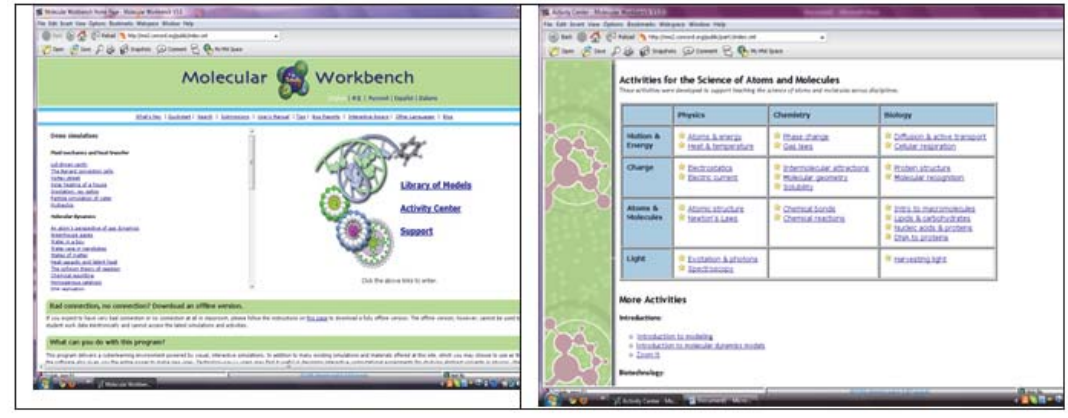

Figure 1 : Molecular Workbench software Activities

The Molecular Workbench helps students visualize what microscopic structures may look like and how they move. Students can experiment with atomic-scale systems to understand a wide variety of concepts such as the kinetic molecular theory, gas laws, diffusion, heat transfer, phase change, chemical reactions, fluid mechanics, material properties, structure-function relationships, the genetic code, protein synthesis, light-matter interactions and quantum phenomena (Figures 2, 3 and 4).
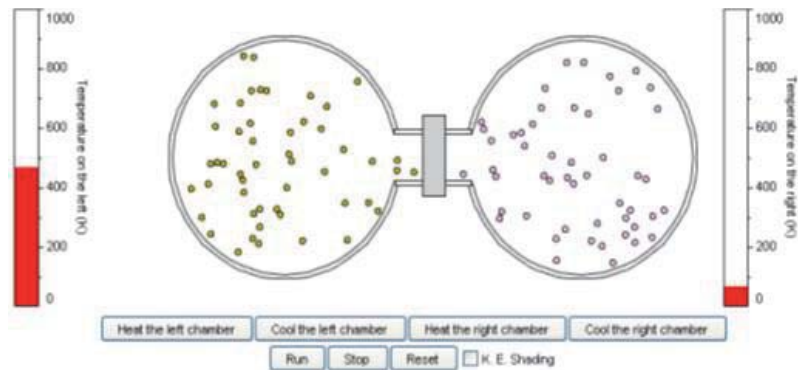

Figure 2 : Virtual experiments 


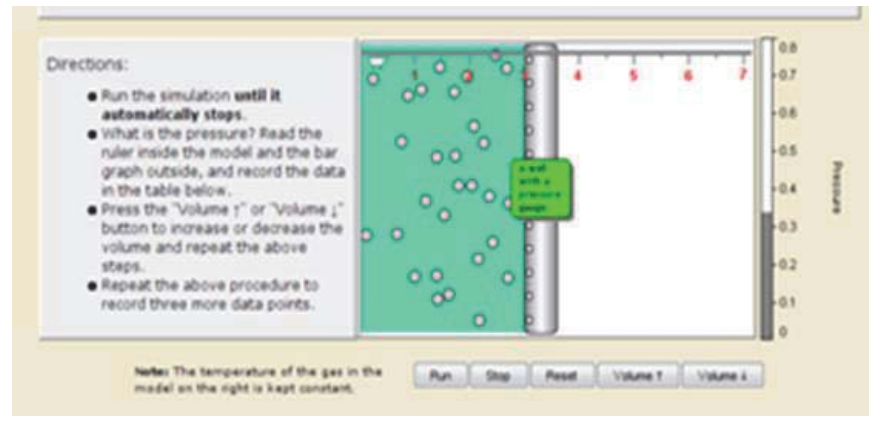

Figure 3: The volume-pressure relationship

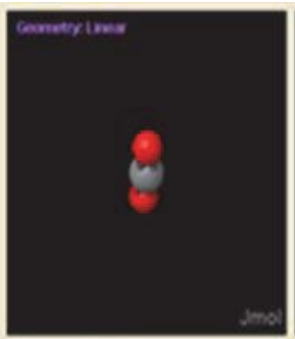

Change Vlew: nomingive.

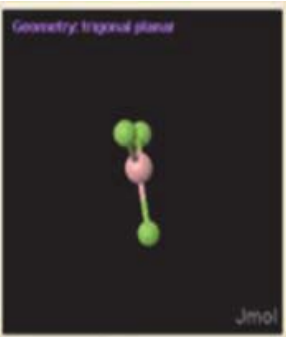

Change Vlew:

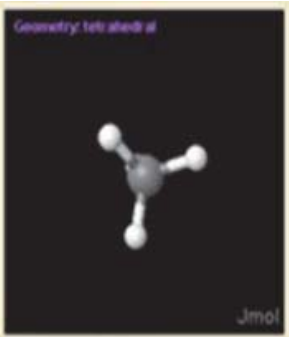
Change View: numirtich.

Figure 4 : Molecular geometry

\subsection{Research Procedure}

This study started with the preparation of modules for both groups based on class sessions of one hour. There were a total of 10 modules which covered all the topics for this study. The experimental test process began with the random selection of two classes with students of average performance. One class was randomly assigned as the control group, to be taught in the traditional manner, while the other class would be learn by using the Molecule Workbench software. Both groups of students that had been tested in the mid-term for chemistry prior to the study were equal in their test performances. Both groups were taught by the same teacher to avoid any bias in the study. Students from the experimental group were brought to the computer lab to use the Molecule Workbench software. Meanwhile, students in the traditional groups will be given the same material with the experimental groups. The only difference between these two groups is that the experimental group will use computer software throughout this study while the traditional group will practice the normal method of teaching as before. After the completion of all ten modules, both groups took a Chemistry Achievement Test that was marked by the same teacher.

\section{Findings}

\subsection{Effects of Molecular Workbench Software on overall post-test performance}

The first analysis was conducted on the students' overall performance in the Chemistry Achievement Test. An independent sample t-test was performed on the post-test scores based on the total marks of all five chemistry topics. The findings showed a significant difference between the control group $(M=14.91, S D=3.10)$ and the experimental group $(\mathrm{M}=18.4, \mathrm{SD}=1.35 \mathrm{t}(68)=6.10, \mathrm{p}=.00)$ (Table 1). The eta squared was calculated as 0.35 . According to Cohen et al. [17] the magnitude of the difference between the means was large. Hence, the first hypothesis was accepted. It may be inferred from this that students gained more from using Molecular Workbench in the learning of chemistry, as compared to the traditional learning approach. 
Table 1 : Overall Independent t-test Result in Chemistry Post-test

\begin{tabular}{lcccccccc}
\hline Group & $\mathrm{N}$ & Mean & SD & SEM & t & df & Sig & Effect size \\
\hline Control & 35 & 14.91 & 3.10 & .524 & & & & \\
\hline & & & & & 6.10 & 68 & $0.000^{\star}$ & 0.59 \\
\hline Experimental & 35 & 18.40 & 1.35 & .228 & & & & \\
\hline
\end{tabular}

Further analysis was performed to evaluate the students' performance on five chemistry topics (Gas Laws, Chemical Bonding, Molecular electronegativity, Molecular geometry and Salt dissolution) tested in the Chemistry Achievement Test. As seen in Table 2, students in the experimental group achieved higher scores in all the five topics tested in the study. The differences in test performance between students taught chemistry conventionally and those taught using the Molecular Workbench software as a teaching and learning aid were statistically significant for each topic. Hence, not only did the software show its usefulness in overall test scores, but this benefit was reflected in all the five chemistry topics. The experimental results suggested that Molecular Workbench Software helped students gain a better understanding in chemistry, and also helped them achieve better test scores compared to their schoolmates who were taught in the conventional way.

Table 2 : Comparison of students' performance in the Chemistry Achievement Post-test

\begin{tabular}{|c|c|c|c|c|c|c|c|c|c|}
\hline Topics & Group & $\mathrm{N}$ & Mean & SD & SEM & $t$ & $\mathrm{df}$ & Sig & Eta Squared \\
\hline \multirow{3}{*}{ Gas Law } & Control & 35 & 2.97 & 1.04 & 0.18 & & & & \\
\hline & & & & & & 4.95 & 68 & $.000^{*}$ & 1.04 \\
\hline & Experimental & 35 & 3.89 & 0.32 & 0.06 & & & & \\
\hline \multirow{3}{*}{ Chemical Bonding } & Control & 35 & 2.54 & 1.04 & 0.17 & & & & \\
\hline & & & & & & 4.63 & 68 & $0.000^{*}$ & 0.239 \\
\hline & Experimental & 35 & 3.48 & 0.61 & 0.10 & & & & \\
\hline \multirow{3}{*}{ Molecular electronegativity } & Control & 35 & 1.94 & 1.51 & 0.26 & & & & \\
\hline & & & & & & 4.97 & 68 & $0.000^{*}$ & 0.266 \\
\hline & Experimental & 35 & 3.37 & 0.77 & 0.13 & & & & \\
\hline \multirow{3}{*}{ Molecular geometry } & Control & 35 & 2.34 & 1.26 & 0.21 & & & & \\
\hline & & & & & & 6.01 & 68 & $0.000^{*}$ & 0.346 \\
\hline & Experimental & 35 & 3.74 & 0.56 & 0.09 & & & & \\
\hline \multirow{3}{*}{ Salt dissolution } & Control & 35 & 2.97 & 1.07 & 0.18 & & & & \\
\hline & & & & & & 4.54 & 68 & $0.000^{*}$ & 0.232 \\
\hline & Experimental & 35 & 3.86 & 0.43 & 0.07 & & & & \\
\hline
\end{tabular}

\subsection{Students' perception towards the usefulness of Molecular Workbench software}

The extent to which the students felt that using the Molecular Workbench software improved their learning of chemistry was evaluated. For this purpose 10 items were developed to measure the perceived usefulness by using 5-Likert scale ranging from 1 (strongly disagree) to 5 (strongly agree). The overall mean score of the student feedback was 3.57 (SD = .928). This indicated that students in experiment group were of the opinion that they benefited from the Molecular Workbench software in learning Chemistry. Table 3 presents the students' perceptions towards each measure of perceived usefulness in using the Molecular Workbench software. 
Table 3 : Students perceived usefulness using the Molecular Workbench software.

\begin{tabular}{clccc}
\hline & Items & $\mathrm{N}$ & Mean & SD \\
\hline 1 & Using workbench software would improve my performance in chemistry course. & 35 & 3.685 & 1.157 \\
2 & I intend to use workbench software whenever available. & 35 & 3.542 & 1.357 \\
3 & I intend to use workbench software frequently when available. & 35 & 3.600 & 1.264 \\
4 & Using workbench would improve chemistry learning productivity. & 35 & 3.771 & 1.190 \\
5 & I find workbench software useful in learning chemistry. & 35 & 3.742 & 0.950 \\
6 & Using workbench software enhances my effectiveness on learning. & 35 & 3.771 & 1.002 \\
7 & Using workbench software improves the quality of learning chemistry. & 35 & 3.800 & 1.106 \\
8 & Workbench software fulfils my learning needs. & 35 & 3.028 & 1.224 \\
9 & I intend to apply in workbench software again in class. & 35 & 3.657 & 1.027 \\
10 & I have planned to apply workbench software at home. & 35 & 3.114 & 1.105 \\
\hline & Total Mean & 3.57 & 9.28 \\
\hline
\end{tabular}

As shown in Table 3, the item with the highest score was Item 7: "Using workbench software improves the quality of learning chemistry" $(M=3.80, S D=1.10)$. This was followed by "Using workbench would improve chemistry learning productivity" (M=3.77, $S D=1.19)$ and the item "Using workbench software enhances my effectiveness on learning" $(M=3.77, S D=1.00)$. The item with the lowest mean score was "Molecular Workbench software fulfils my learning needs" $(\mathrm{M}=3.02, \mathrm{SD}=1.22)$.

\section{Discussion}

This study was undertaken with the objective to investigate the usefulness of the Molecular Workbench software on the learning of chemistry by secondary school students. The five chemistry topics involved in this study were gas laws, chemical bonding, molecular electronegativity, molecular geometry and salt dissolution. The results revealed that students in the experimental group performed significantly better in all topics than their schoolmates who were taught the same topics by the conventional approach. This finding was consistent with the earlier reports of Barnea and Dori (1999), Chang (2001), Morgil et. al. (2005), Akcay et. al (2006), Frailich et. al (2007), Dasdemir et. al (2008), Ozmen (2008) and Abdoolatiff and Narod (2009) who found that integrating technology in teaching and learning Chemistry enhanced students' learning and test performance.

One of the advantages using Molecular Workbench for the topic, gas laws, was that the students could understand the nature of molecules and their motion. They also had the opportunity to experience the computer graphics illustrating the changing of temperature and pressure on gas volume. Such graphics enabled a better grasp of the subject than could be attained by explanations by the teacher writing or drawing on the board. In the molecular electronegativity topic, students were able to see the atoms being manipulated to illustrate the effects of electronegativity. This helped the students to answer the questions pertaining to this topic in the test. By using Molecular Workbench software, students could visualize the shape of the molecules in a 3-dimensional environment. This software also showed students the effects of non-bonding electron pairs on the shape of the molecules in the spatial environment. Molecular Workbench enabled the students to observe how water molecules with positive and negative polarity could interact with a crystal of salt, and how ions of a salt diffused in water. Students in the experimental group could explain the reasons for salt dissolution in water better than the control group.

\section{Conclusion}

This study investigated the effectiveness of Computer Assisted Instruction approach in the learning of chemistry as compared with traditional approach. The results obtained supported the proposition that appropriate computer software could play an important role in teaching and learning science. Classroom instructions on the concepts of macroscopic chemical properties and symbolic representations aim to impart to students an understanding of various chemistry concepts. In this regard, the conventional teaching approach has limitations in that students may find it difficult to visualize the nature and movement of atoms and molecules. Computer software can therefore complement the effort of the teacher, who serves as a facilitator of learning using modern information technology. In so doing, the teacher moves beyond his traditional role as purely a source of factual information for students. 


\section{References}

Abdoolatiff, S. \& F.B. Narod (2009), Investigating the Effectiveness of Computer Simulations in the Teaching of "Atomic Structure and Bonding", in Chemistry Education in the ICT Age. 2009, Springer Netherlands. 85-100.

Akcay, H., Durmaz, A., Tuysuz, C., \& Feyzioglu, B. (2006). Effects of Computer Based Learning on Students' Attitudes and Achievements towards Analytical Chemistry. Turkish Online Journal of Educational Technology, 5(1), 44-48.

Barnea, N., \& Dori, Y. (1996). Computerized molecular modeling as a tool to improve chemistry teaching. Journal of Chemical Information and Computer Sciences, 36(4), 629-636.

Barak, M. (2007). Transition from Traditional to ICT-Enhanced Learning Environments in Undergraduate Chemistry Courses. Computers and Education, 48(1), 30-43.

Barnea, N. \& Dori, Y (1999) High-school chemistry students' performance and gender differences in a computerized molecular modeling learning environment. Journal of Science Education and Technology. 8(4),257-271.

Cepni, S., Tas, E., \& Kose, S. (2006). The effects of computer-assisted material on students' cognitive levels, misconceptions and attitudes towards science. Computer Education, 46(2), 192-205.

Chang, C.-Y. (2001) Comparing the Impacts of a Problem-based Computer-Assisted Instruction and the Direct-Interactive Teaching Method on Student Science Achievement. Journal of Science Education and Technology. 10(2), 147-53.

Cohen, L., Manion, L. \& Morrison, K. (2007) Research methods in education 6th Ed. New York: Tylore and Francis Library

Dasdemir, I., Doymus, K., Simsek, Ü., \& Karaçöp, A. (2008). The effects of animation technique on teaching of acids and bases topics. Journal of Turkish Science Education, 5(2), 60-69.

Demirad, B., Kartal, M., \& Tuysuz, C. (2008). Developing A Computer Assisted Education Material Related To Thermochemistry. Journal of Turkish Science Education, 5, 60-71.

Frailich, M., Kesner, M., \& Hofstein, A. (2007). The Influence of Web-Based Chemistry Learning on Students' Perceptions, Attitudes, and Achievements. Research in Science \& Technological Education, 25(2), 179-197.

Gobert, J., Snyder, J., \& Houghton, C. (2002). The influence of students' understanding of models on model-based reasoning: University of Kansas : National Science Foundation.

Johnstone A.H., (1982), Macro- and micro- chemistry. School Science Review, 64 (227), 377-379.

Kiboss, J. K., Ndirangu, M., \& Wekesa, E. W. (2004). Effectiveness of a Computer-Mediated Simulations Program in School Biology on Pupils' Learning Outcomes in Cell Theory. Journal of Science Education and Technology, 13(2), 207-213.

Morgil, I., Yavuz, S., Oskay, O., \& Arda, S. (2005). Traditional and computer-assisted learning in teaching acids and bases. Chemistry Education Research and Practice, 6(1), 52-63.

Ozmen, H., Ayas, A., \& Costu, B. (2002). Determination of the science student teachers' understanding level and misunderstandings about the particulate nature of the matter. Educational Sciences: Theory and Practice, 2(2), 506-529.

Ozmen, H. \& Kolomuc, A. (2004). Effect of computer-based teaching on students' achievement in solution chemistry. Kastamonu Education Journal, 12(1), 57-68.

Ozmen, H. (2008). The influence of computer-assisted instruction on students' conceptual understanding of chemical bonding and attitude toward chemistry: A case for Turkey. Computer Education, 51(1), 423-438.

Smeets, E (2005). Does ICT contribute to powerful learning environments in primary education?. Computer Education, 44(3), $343-355$.

Smith, E. L., Blakeslee, T. D., \& Anderson, C. W. (1993). Teaching strategies associated with conceptual change learning in science. Journal of Research in Science Teaching, 30(2), 111-126.

Treagust, D.F., Chittleborough, G \& Mamiala, T.L. (2003) The Role of Submicroscopic and Symbolic Representations in Chemical Explanations. International Journal of Science Education, 25(11), 1353-1368.

.Tsai, C.-C. (2000). Enhancing science instruction: the use of 'conflict maps'. International Journal of Science Education, $22(3), 285$ 302.

Tyson, L., Treagust, D. F., \& Bucat, R. B. (1999). The Complexity of Teaching and Learning Chemical Equilibrium. Journal of Chemical Education, 76(4), 554.

Yuruk, N. (2007). The Effect of Supplementing Instruction with Conceptual Change Texts on Students' onceptions of Electrochemical Cells. Journal of Science Education and Technology, 16(6), 515-523 
